\title{
Total polyphenols contents in different grapevine varieties in highlands of southern brazil
}

\author{
Emilio Brighenti ${ }^{1}$, Katia Casagrande ${ }^{2}$, Paula Zelindro Cardoso ${ }^{2}$, Mateus da Silveira Pasa ${ }^{1}$, Marlise Nara Ciotta ${ }^{1}$, \\ and Alberto Fontanella Brighenti ${ }^{1}$ \\ ${ }^{1}$ Santa Catarina State Agricultural Research and Rural Extension Agency (EPAGRI), João Araújo Lima St., 102, São Joaquim, \\ Santa Catarina State, Brazil \\ ${ }^{2}$ University of South Santa Catarina (UNISUL), José Acácio Moreira Av., 787, Tubarão, Santa Catarina State, Brazil
}

\begin{abstract}
Phenolic compounds are one of the main parameters of wine quality and contribute to the organoleptic characteristics, particularly color, astringency and body. In the highlands of southern Brazil, low temperatures and high accumulation of global solar radiation favor the synthesis of total polyphenols in grapes. The objective of this work was to evaluate the concentration of total polyphenols of 10 white varieties and 13 red varieties produced in high altitude regions of southern Brazil. The vineyard is located in the Experimental Station of Santa Catarina State Agricultural Research and Rural Extension Agency (EPAGRI), in the city of São Joaquim ( $28^{\circ} 16^{\prime} 30^{\prime \prime} \mathrm{S}, 49^{\circ} 56^{\prime} 09^{\prime \prime} \mathrm{W}$, Altitude $\left.1,400 \mathrm{~m}\right)$, the evaluations occurred in 2015/2016 growing season. The content of total polyphenols was determined as proposed by Singleton \& Rossi (1965), using the Folin-Ciocalteu method, with spectrophotometer readings. Polyphenol content ranged from 283.56 to $1,387.31 \mathrm{mg} / \mathrm{L}$ for white varieties, the varieties with the highest concentrations were Greco di Tufo $(1,378.31 \mathrm{mg} / \mathrm{L})$, Trebbiano Toscano $(995.59 \mathrm{mg} / \mathrm{L})$ and Ribola Gialla $(737.48 \mathrm{mg} / \mathrm{L})$. For the red varieties, the total polyphenol content ranged from 523.87 to $4,929.57 \mathrm{mg} / \mathrm{L}$, Ancellotta $(4,929.57 \mathrm{mg} / \mathrm{L})$, Uva di Troia $(2,722.27 \mathrm{mg} / \mathrm{L})$ and Croatina $(2,410 \mathrm{mg} / \mathrm{L})$ stood out for presenting the highest levels.
\end{abstract}

\section{Introduction}

The wine production in high altitude regions of Santa Catarina State has less than 15 years of history and is relatively recent, when compared with other producing regions in Brazil. Today in high altitude regions of Santa Catarina State, there are 35 wineries in operation, with a planted area of 600 hectares and over 200 labels of white, red and sparkling wines. In high-altitude vineyards of Santa Catarina, the main varieties planted are Cabernet Sauvignon, Merlot and Sauvignon Blanc [1].

The enlargement of the varietal choice is a powerful tool in the hands of grape growers and winemakers in the highly competitive wine market; however, it should not be repeated the error of relying on few varieties either local or imported. The French varieties, it has to be reminded, are spread all over the viticultural world. In addition, some practices largely adopted in modern winemaking emphasized the globalization of wine taste minimizing on this respect the contribution of the variety and of the environment of production. In such a situation, the most forward thinking wine producers are starting to again look at local varietal heritage, re-examining their enological value and marketing potential [2].

When introducing new grape varieties, the phenology and ripening monitoring are important in determining the ability of a region to produce a crop within the confines of its climate regime [3]. Grape ripening encompasses the period that starts with the color change (véraison) and ends at harvest, and varies according to the variety and the region. Among the modifications that occur in the berries and, therefore, in the composition of the grape during the ripening are pigment accumulation in the skin, synthesis of aromatic substances and flavor modification $[4,5]$.

These modifications are related to the synthesis of phenolic compounds, the grape is one of the major sources of phenolic compounds, which are mainly found in the skin and in the seed, presenting little content in the pulp [6].

Phenolic compounds are important for plant growth and reproduction, also acting as antipathogens (stress conditions such as infections and wounds) and protection against UV radiation [7]. They still contribute to pigmentation, astringency, aromas and oxidative stability. In viticulture these compounds are responsible for the qualitative and organoleptic composition of wines, such as color, body and astringency [8].

The synthesis and accumulation of phenolic compounds are greatly influenced by the environment conditions, including light, air temperature, altitude, soil type, water availability, nutritional status, disease incidence and other developmental processes $[9,10]$.

The objective of this work was to evaluate the concentration of total polyphenols of 10 white varieties and 13 red varieties produced in high altitude regions of southern Brazil.

\section{Materials and methods}

The experiments was conducted in variety collection of the Experimental Station of Santa Catarina State Agricultural Research and Rural Extension Agency (EPAGRI), located in the city of São Joaquim $\left(28^{\circ} 16^{\prime} 30^{\prime \prime} \mathrm{S}, 49^{\circ} 56^{\prime} 09^{\prime \prime} \mathrm{W}\right.$, 
Altitude $1,400 \mathrm{~m}$ a.s.l.). The vineyard was planted in 2006, spacing $3.00 \mathrm{~m}$ between rows and $1.50 \mathrm{~m}$ between plants, the training system adopted was VSP and evaluations occurred in the 2015/2016 growing season.

The climate of the region is characterized as humid subtropical, without dry season, with annual mean temperature and rainfall of $13.5^{\circ} \mathrm{C}$ and $1,700 \mathrm{~mm}$, respectively. According to the Köppen classification, the climate is Cfb. The soils are classified as Haplumbrept and Udorthent developed from rhyodacite and basalt rock [11].

The evaluated white grape varieties were Riesling Renano, Verdelho, Marsanne, Petit Manseng, Moscato Giallo, Fiano, Chardonnay, Ribola Gialla, Trebbiano Toscano and Greco di Tufo. The evaluated red grape varieties were Negroamaro, Pinot Nero, Canaiolo Nero, Malvasia Nera, Barbera, Cabernet Sauvignon, Marselan, Merlot, Aglianico, Syrah, Croatina, Uva di Troia and Ancellotta.

Climatic data, like precipitation (mm), relative humidity (\%), maximum, minimum and mean air temperature $\left({ }^{\circ} \mathrm{C}\right)$ and sunshine (h) were measured on site with an automatic weather station from CIRAM (Center of Environmental Resources Information and Hydrometeorology of Santa Catarina).

For quantification of the grapes phenolic content the extract used was obtained as follows: grape skins were carefully removed from 90 berries and used for the extraction process of the phenolic ripening analysis [12].

To obtain extract solutions, the following skin and extract ratio was used: $50 \mathrm{~g}$ of skins were separated manually from berries samples, which were added $20 \mathrm{~mL}$ of hydroalcoholic solution of methanol $50 \% \mathrm{v} / \mathrm{v}$, and maintained At $30^{\circ} \mathrm{C}\left(+0.5^{\circ} \mathrm{C}\right)$ for 24 hours. After this time, the "hot" extract was separated and the skins were rinsed with $5 \mathrm{~mL}$ of the methanol solution. After this, $20 \mathrm{~mL}$ of methanol extracting solution were added to the skins, which were then placed at $0^{\circ} \mathrm{C}\left(+0.5^{\circ} \mathrm{C}\right)$ for further 24 hours. After this extraction, the "cold" extract was homogenized with the "hot" extract, and the skin rinsing was repeated with another $5 \mathrm{~mL}$ of methanol solution. The extract solution was filtered at the end of the process [12].

The concentration of skin total polyphenols was quantified in spectrophotometer, using the reagent FolinCiocalteu (Vetec) and gallic acid as standard, with absorbance readings at $760 \mathrm{~nm}$ [13]. The calibration curve was made using the concentrations of $0,100,200,300$, $400,500,600$ and $1000 \mathrm{mg} / \mathrm{L}$. The results were expressed in $\mathrm{mg} / \mathrm{L}$ of gallic acid.

Data were submitted to analysis of variance (ANOVA, $p \leq 0.05$ ), and when variety effects were detected, the Tukey test was performed $(\mathrm{p} \leq 0.05)$.

\section{Results and discussion}

The climate is one of the basic aspects in the grape culture and, consequently, for the viticulture. Viticulture for the wine production is developed in many types of climate and soil in the different continents [14]. A survey of world viticultural areas can indicate relationship between climate and quality [4]. Thus, the monitoring of the climatic parameters are important because these influence both grape and wine quality [3].

Grape ripening period occurred between January and April and the climatic parameters for the period are
Table 1. Climatic parameters obtained with meteorological station, from véraison to harvest, during the growing season 2015/2016, in São Joaquim - Santa Catarina State, Brazil.

\begin{tabular}{|l|c|c|c|c|c|}
\hline Climatic Parameters & Jan & Feb & Mar & Apr & Mean \\
\hline Maximum Temp. $\left({ }^{\circ} \mathrm{C}\right)$ & 23.4 & 23.5 & 20.7 & 21.0 & 22.2 \\
\hline Minimum Temp. $\left({ }^{\circ} \mathrm{C}\right)$ & 13.4 & 14.6 & 11.2 & 12.7 & 13.0 \\
\hline Mean Temp. $\left({ }^{\circ} \mathrm{C}\right)$ & 17.8 & 18.4 & 15.4 & 16.1 & 16.9 \\
\hline Termal Amplitude $\left({ }^{\circ} \mathrm{C}\right)$ & 10.0 & 8.9 & 9.5 & 8.3 & 9.2 \\
\hline Relative Humidity $(\%)$ & 83.2 & 85.3 & 84.2 & 80.2 & 83.2 \\
\hline Precipitation $(\mathrm{mm})$ & 119.9 & 177.5 & 159.4 & 157.9 & 614.7 \\
\hline Rainy Days $(\mathrm{n})$ & 10 & 20 & 12 & 14 & 56 \\
\hline Rainy Days $(\%)$ & 32 & 69 & 39 & 47 & 47 \\
\hline Sunshine hours $(\mathrm{h})$ & 198.3 & 160.2 & 180.5 & 155.4 & 694.4 \\
\hline
\end{tabular}

shown in Table 1. Temperatures observed in this phase confirm the potential for wine production in the region, due to temperature reduction and substantial thermal amplitude during fruit ripening. Another authors reported for the region of São Joaquim thermal amplitude around $10^{\circ} \mathrm{C}$, which is favorable for production of quality grapes $[3,15,16]$.

The climatic conditions of São Joaquim favored grape phenolic maturation, since the accumulation of anthocyanins during maturation presents negative correlation with high temperatures and positive with low temperatures. The grapes present a good coloration when the thermal amplitude does not exceed $10^{\circ} \mathrm{C}$ and during maturation it must be below $15^{\circ} \mathrm{C}$ [17].

During grape ripening, the observed amount of precipitation was $614.7 \mathrm{~mm}$. The frequency and distribution of rainfall are climatic elements of great importance, because the free water on the leaves and the fruit is the main factor to trigger the onset of fungal infections on the vine [18]. The high rate and frequency of rainfall is the main limiting climatic factor of vine cultivation in high altitude regions of southern Brazil [19].

The precipitation is an important climatic factor in terms of the formation of phenolic compounds in the skin of the grapes [20]. Polyphenols have the function of protecting plants from physical (such as the sun UV radiation) and biological (fungi, viruses, bacteria) attacks. Typically, in places where there are high rainfall levels, there is stress from the plant to combat, mainly, fungal diseases, inducing the production of phenolic compounds $[9,10,21]$.

The accumulation of sunshine hours during grape ripening was higher in São Joaquim (694.4 hours) than in other grapevine producing regions of Santa Catarina State. The regions of Campo Belo do Sul, Bom Retiro and Água Doce showed 546, 571 and 288 sunshine hours, respectively, during ripening of different varieties $[16,22]$. In São Joaquim, during the growing seasons of 2005/2006 and 2006/2007 it was reported the average of 424 sunshine hours during the ripening of four Vitis vinifera L. varieites [3]. This climatic parameter is important because it is directly related to fruit quality, stimulating mainly the accumulation of phenolic compounds such as anthocyanins [5].

The incidence of solar radiation in grape clusters also contributes to the activation of metabolism and the formation of substances responsible for wine quality, such as phenolic compounds, especially flavonols [9]. This 
Table 2. Date of occurrence from véraison to harvest phases for the white varieties evaluated during 2015/2016 growing season, in São Joaquim - Santa Catarina State, Brazil.

\begin{tabular}{|l|c|c|c|c|}
\hline Variety & Véraison & Harvest & $\begin{array}{c}\text { Ripening } \\
\text { Duration }\end{array}$ & $\begin{array}{c}\text { Total cycle } \\
\text { (days) }\end{array}$ \\
\hline Riesling R. & 25-jan & 9-mar & 44 & 192 \\
\hline Verdelho & 9-feb & 28-mar & 48 & 203 \\
\hline Marsanne & 14 feb & 28-mar & 43 & 196 \\
\hline P. Manseng & 2-feb & 28-mar & 55 & 194 \\
\hline Moscato G. & 10-feb & 22-mar & 41 & 189 \\
\hline Fiano & 11-feb & 28-mar & 46 & 202 \\
\hline Chardonnay & 19-jan & 16-mar & 57 & 208 \\
\hline Ribola G. & 31-jan & 28-mar & 57 & 205 \\
\hline Trebbiano T. & 15-feb & 5-apr & 50 & 196 \\
\hline Greco di Tufo & 10-feb & 15-apr & 55 & 223 \\
\hline
\end{tabular}

Table 3. Date of occurrence from véraison to harvest phases for the red varieties evaluated during 2015/2016 growing season, in São Joaquim - Santa Catarina State, Brazil.

\begin{tabular}{|l|c|c|c|c|}
\hline Variety & Véraison & Harvest & $\begin{array}{c}\text { Ripening } \\
\text { Duration }\end{array}$ & $\begin{array}{c}\text { Total cycle } \\
\text { (days) }\end{array}$ \\
\hline Negroamaro & 12-feb & 5-apr & 53 & 200 \\
\hline Pinot Nero & 17-jan & 1-mar & 44 & 183 \\
\hline Canaiolo N. & 11-feb & 28-mar & 46 & 201 \\
\hline Malvasia N. & 13-feb & 28-mar & 44 & 192 \\
\hline Barbera & 6-feb & 22-mar & 45 & 190 \\
\hline Cabernet S. & 6-feb & 22-mar & 45 & 186 \\
\hline Marselan & 5-feb & 22-mar & 46 & 200 \\
\hline Merlot & 4-feb & 22-mar & 47 & 186 \\
\hline Aglianico & 15-feb & 5-apr & 50 & 201 \\
\hline Syrah & 7-feb & 5-apr & 58 & 211 \\
\hline Croatina & 10-feb & 28-mar & 47 & 192 \\
\hline Uva di Troia & 10-feb & 28-mar & 47 & 188 \\
\hline Ancellotta & 29-jan & 28-mar & 59 & 194 \\
\hline
\end{tabular}

difference can give to the wines high altitude regions of Santa Catarina State more intense coloration, more complex aroma, greater structure and persistence [3,22].

The mean date of occurrence and extent of phenological cycle, between véraison and harvest, are shown in Tables 2 and 3. Greco di Tufo (white) and Syrah (red) were the varieties with the longest cycle with 223 and 211 days respectively. Among white varieties, Chardonnay, Ribola Gialla, Greco di Tufo and Petit Manseng presented the longest duration of grape ripening. While for the red varieties, Ancellotta and Syrah presented the longest ripening duration.

The extension of the phenological cycle is related to climatic conditions of each region. In Brazilian climatic conditions, regions of high altitude (above 900 meters a.s.1.), present longer phenological cycles due to the occurrence of lower temperatures [15, 19,23].

Significant differences were observed in polyphenol contents between the different varieties (Figs. 1 and 2). although the environmental conditions under which the grapes were grown have a great influence on the synthesis of polyphenolic compounds, the nature and the different concentration of these compounds follow the determinant genetics of each variety [24].

Many authors have reported that polyphenol composition is due not only to the type of cultivar but also to the location where the grapes are grown and environmental

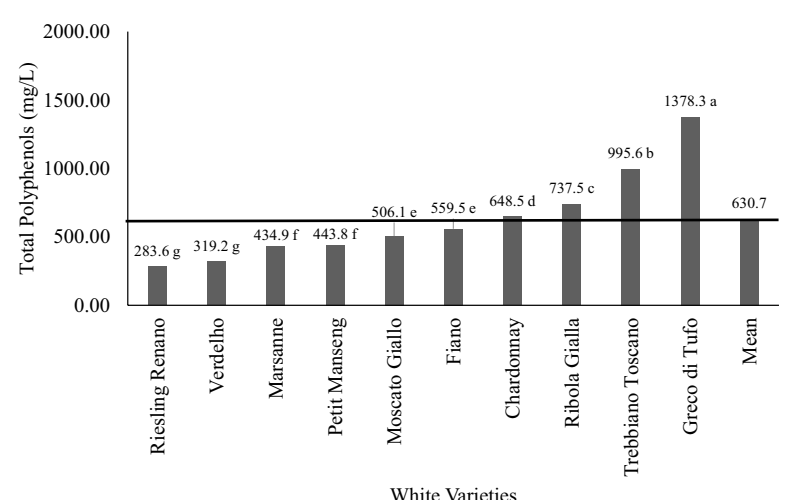

Figure 1. Total polyphenols concenttration $(\mathrm{mg} / \mathrm{L})$ in berries of different white varieties grown in São Joaquim - Santa Catarina State, Brazil, during the growing season of 2015/2016.

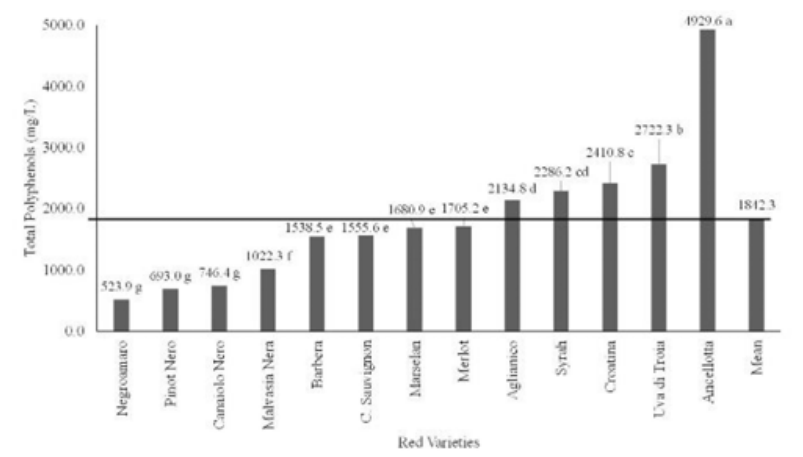

Figure 2. Total polyphenols concenttration $(\mathrm{mg} / \mathrm{L})$ in berries of different red varieties grown in São Joaquim - Santa Catarina State, Brazil, during the growing season of 2015/2016.

and management practices, as well as the growing season $[4,20,25]$.

Polyphenol content ranged from 283.56 to $1,387.31 \mathrm{mg} / \mathrm{L}$ for white varieties. For the red varieties, the total polyphenol content ranged from 523.87 to $4,929.57 \mathrm{mg} / \mathrm{L}$. The main phenolic compounds found in grapes and wines are classified as: non-flavonoids and flavonoids [26]. Flavonoid compounds represent the largest group of polyphenols found in foods, presenting high antioxidant power [27]. The most common flavonoids present in grapes and red wines include anthocyanins, flavanols and flavonols. These compounds are responsible for color and structure characteristics of wines [9]. Therefore the concentration of total polyphenols is on average higher in the red varieties.

The white varieties with the highest concentrations of total polyphenols were Greco di Tufo $(1,378.31 \mathrm{mg} / \mathrm{L})$, Trebbiano Toscano (995.59 mg/L) and Ribola Gialla $(737.48 \mathrm{mg} / \mathrm{L})$, while Riesling Renano $(283.56 \mathrm{mg} / \mathrm{L})$, Verdelho (319.16 mg/L) and Marsanne (434.87 mg/L) presented the lowest values.

In southern Italy, the average total polyphenols ranged from 491.6 to $536.8 \mathrm{mg} / \mathrm{L}$ for different white grape varieties [28]. While in Água Doce - Santa Catarina State, Brazil, the average total polyphenols ranged from 601 to $706 \mathrm{mg} / \mathrm{L}$ [16]. In Água Doce, the value obtained for Fiano was $601 \mathrm{mg} / \mathrm{L}$, quite similar to those obtained in this study $(559.5 \mathrm{mg} / \mathrm{L})$. While in São Joaquim, it was found values of $474.94 \mathrm{mg} / \mathrm{L}$ for Prosecco, 517.32 for Vermentino and 540.04 for Verdicchio [15]. 
Considering red varieties, Ancellotta (4,929.57 mg/L), Uva di Troia $(2,722.27 \mathrm{mg} / \mathrm{L})$ and Croatina $(2,410 \mathrm{mg} / \mathrm{L})$ stood out for presenting the highest levels of total polyphenols, while Negroamaro $(523.87 \mathrm{mg} / \mathrm{L})$, Pinot Nero $(692.98 \mathrm{mg} / \mathrm{L})$ and Canaiolo Nero $(746.38 \mathrm{mg} / \mathrm{L})$ presented the lowest levels of total polyphenols.

In a study performed in Calabria/Italy, with four different red grape varieties, it was found variations in polyphenol contents from 1,503 to $2,170 \mathrm{mg} / \mathrm{L}$. The diversity of results found, is probably related to several factors, among them: the variety, management practices, methods of extraction and analysis used [29].

While in Água Doce - Santa Catarina State, Brazil, the average total polyphenols ranged from 570 to $2,217 \mathrm{mg} / \mathrm{L}$ to four red varieites [16]. In Água Doce, the variety Ancellotta stood out with the highest concentration of total polyphenols $(2,217 \mathrm{mg} / \mathrm{L})$, that value was lower the observed in São Joaquim, for the same variety $(4,929.57 \mathrm{mg} / \mathrm{L})$. In São Joaquim, during the growing seasons of 2010/2011, 2011/2012 and 2012/2013 it was found values between 734.2 and $2,515.1 \mathrm{mg} / \mathrm{L}$ for 9 red Italian varieties, in this work, the varieties Aglianico $(1,730.7 \mathrm{mg} / \mathrm{L})$ and Ancellotta $(2,515.1 \mathrm{mg} / \mathrm{L})$ stood out with highest total polyphenols concentration [15].

It is believed that high altitude is related to the high concentration of total polyphenols obtained in grapes grown in São Joaquim. Among the environmental factors, climate exerts the greatest influence on the accumulation of polyphenols; the higher the altitude, the lower the temperature and humidity and the higher the incidence of solar radiation, which favors the accumulation of total polyphenols $[9,30]$. In this case, the causes of the greatest accumulation of total polyphenols may be related to the quantity and quality of solar radiation and thermoperiod, which are effects of altitude [19].

\section{Conclusion}

Significant differences were observed in polyphenol contents between the different varieties. This fact evidences the interaction between genotype and environment as one of the main factors related to accumulation and concentration of grape polyphenols.

Polyphenol content ranged from 283.56 to $1,387.31 \mathrm{mg} / \mathrm{L}$ for white varieties, the varieties with the highest concentrations were Greco di Tufo (1,378.31 $\mathrm{mg} / \mathrm{L})$, Trebbiano Toscano (995.59 mg/L) and Ribola Gialla (737.48 mg/L), while Riesling Renano (283.56 mg/L), Verdelho (319.16 mg/L) and Marsanne (434.87 mg/L) presented the lowest values.

For the red varieties, the total polyphenol content ranged from 523.87 to $4,929.57 \mathrm{mg} / \mathrm{L}$, Ancellotta $(4,929.57 \mathrm{mg} / \mathrm{L})$, Uva di Troia $(2,722.27 \mathrm{mg} / \mathrm{L})$ and Croatina $(2,410 \mathrm{mg} / \mathrm{L})$ stood out for presenting the highest levels, while Negroamaro $(523.87 \mathrm{mg} / \mathrm{L})$, Pinot Nero $(692.98 \mathrm{mg} / \mathrm{L})$ and Canaiolo Nero $(746.38 \mathrm{mg} / \mathrm{L})$ presented the lowest levels of total polyphenols.

\section{References}

[1] A.F. Brighenti, E. Brighenti and M.S. Pasa. Vitivinicultura de altitude: realidade e perspectivas. Agropecuária Catarinense 29, 140-146 (2016)
[2] F. Mannini. Italian indigenous grapevine cultivars: guarantee of genetic biodiversity and economic resources. Acta Hort. 652, 8795 (2004)

[3] E.F. Gris, V.M. Burin, E. Brighenti, H. Vieira and M.T. Bordignon-Luiz. Phenology and ripening of Vitis vinifera L. grape varieties in São Joaquim, southern Brazil: a new South American wine growing region. Cien. Inv. Agr. 37, 61-75 (2010)

[4] D.I. Jackson and P.B. Lombard. Environmental and management practices affecting grape composition and wine quality. A review. Am. J. Enol. Vitic. 44, 409-430 (1993)

[5] R.V. Mota, M.A. Regina, D.A. Amorim and A.C. Fávero. Fatores que afetam a maturação e a qualidade da uva para vinificação. Inf. Agrop. 27, 56-64 (2006)

[6] G. Sanna, S. Ledda, G. Manca and M.A. Franco. Characterization of the content of antioxidant substances in the wines of Sardinia. Journal of Commodity Science, Technology and Quality 47, 5-25 (2008)

[7] D. Rusjan, R. Veberic and M. Mikulic-Petkovsek. The response of phenolic compounds in grapes of the variety 'Chardonnay' (Vitis vinifera L.) to the infection by phytoplasma Bois noir. European journal of plant pathology 133, 1-10 (2012)

[8] M. Naczk and F. Shahidi. Extraction and analysis of phenolics in food. Journal of Chromatography 1054, 95-111 (2004)

[9] M.O. Downey, N.K. Dokoozlian and M.P. Krstic. Cultural practice and environmental impacts on the flavonoid composition of grapes and wine: a review of recent research. American Journal of Enology and Viticulture 57, 257-268 (2006)

[10] Z.W. Dai, N. Ollat, E. Gomès, S. Decroocq, J.P. Tandonnet, L. Bordenave, P. Pieri, G. Hilbert, C. Kappel, C.V. Leeuwen, P. Vivin and S. Delrot. Ecophysiological, Genetic, and Molecular Causes of Variation in Grape Berry Weight and Composition: A Review. American Journal of Enology and Viticulture 62, 413-425 (2011)

[11] Embrapa. Centro Nacional de Pesquisa de Solos. Solos do Estado de Santa Catarina (Rio de Janeiro: Embrapa Solos, Boletim de Pesquisa e Desenvolvimento 46, 726, 2004)

[12] J.L. Marcon Filho, J.S. Hipólito, T.A. de Macedo, A.A. Kretzschmar and L. Rufato. A survey of clusters thinning in the 'Cabernet Franc' winemaking potential in two seasons. Ciencia Rural 45, 2150-2156 (2015)

[13] V.L. Singleton and J.A. Rossi. Colorymetry of total phenolics with phosphomolibdic- phosphotungstic acid reagent. Am. J. Enol. Vitic. 16, 144-158 (1965)

[14] J. Tonietto and A. Carbonneau. A multicriteria climatic classification system for grape growing regions worldwide. Agricultural and Forest Meteorology 124, 81-97 (2004)

[15] A.F. Brighenti, A.L. Silva, E. Brighenti, D. Porro and M. Stefanini. Viticultural performance of native Italian varieties in high-altitude conditions in Southern Brazil. Pesq. Agropec. Bras. 49, 465-474 (2014)

[16] L.I. Malinovski, A.F. Brighenti, M. Borghezan, M.P. Guerra, A.L. Silva, D. Porro, M. Stefanini and 
H.J. Vieira. Viticultural performance of Italian grapevines in high altitude regions of Santa Catarina State, Brazil. Acta Hort. 1115, 203210 (2016)

[17] J.M. Ubalde, X. Sort, A. Zayas and R.M. Poch. Effects of Soil and Climatic Conditions on Grape Ripening and Wine Quality of Cabernet Sauvignon. Journal of Wine Research 21, 1-17 (2010)

[18] G. Chavarria, H.P. Santos, O.R. Sônego, G.A.B. Marodin, H. Bergamaschi and L.S. Cardoso. Incidência de doenças e necessidade de controle em cultivo protegido de videira. Rev. Bras. Frutic. 29, 477-482 (2007)

[19] A.F. Brighenti, L.I. Malinovski, M. Stefanini, H.J. Vieira and A.L. Silva. Comparison between the wine producing regions of São Joaquim - SC, Brazil and San Michele All'Adige - TN, Italy. Rev. Bras. Frutic. 37, 281-288 (2015)

[20] G.V. Jones and R.E. Davis. Climate Influences on Grapevine Phenology, Grape Composition, and Wine Production and Quality for Bordeaux, France. American Journal of Enology and Viticulture 51, 249-261 (2000)

[21] C.R.C. Buffara, F. Angelotti, F.A. Vieira, A. Bogo, D.J. Tessmann and B.P. de Bem. Elaboration and validation of a diagrammatic scale to assess downy mildew severity in grapevine. Cienc. Rural 44, 13841391 (2014)

[22] L.I. Malinovski, L.J. Welter, A.F. Brighenti, H.J. Vieira, M.P. Guerra and A.L. Silva. Highlands of Santa Catarina/Brazil: A region with high potential for wine production. Acta Hort. 931, 433439 (2012)

[23] A.F. Brighenti, E. Brighenti, V. Bonin and L. Rufato. Phenological characterization and thermic requirement of distinct grapevines varieties in São Joaquim, Santa Catarina - Brazil. Ciência Rural 43, 11621167 (2013)

[24] A. Calò, D. Tomasi and R. Di Stefano. Relationship between environmental factors ant the dynamics of growth and composition of the grapevine. Acta Hort. 427, 217-231 (1996)

[25] N. Mateus, J.M. Machado and V. Freitas. Development changes of anthocyanins in Vitis vinifera grapes grown in the Douro Valley and concentration in respective wines. J. Scie. Food Agric. 82, 1689-1695 (2002)

[26] G. González-Neves, G. Gil, F. Guzmán and M. Ferrer. Potencial polifenólico de la uva: índices propuestos y posibles aplicaciones. Comunicata Scientiae 2, 57-69 (2011)

[27] A. Scalbert and G. Williamson. Dietary intake and bioavailability of polyphenols. Journal of Nutrition 130, 2073-2085 (2000)

[28] Fanara, C. Evoluzione dei composti polifenolici in vini bianchi della sardegna durante la conservazione in bottiglia e caratterizzazione aromatica, Thesis (Sassari, Italy: Dottorato in Biotecnologie Microbiche Agroalimentari, Universitaĺ degli Studi di Sassari, 2011)

[29] A.M. Giuffrè̀. Polifenoli totali nelle bucce di uve rosse in vitigni calabresi. Industrie delle bevande $\mathbf{2 2 7}$, 18-21 (2010)

[30] N. Mateus, S. Marques, A.C. Gonçalves, J.M. Machado and V. de Freitas. Proanthocyanidin composition of red Vitis vinifera varieties from the Douro valley during ripening: influence of cultivation altitude. American Journal of Enology and Viticulture 52, 115-121 (2001) 